УДК 636.52/.58:612.397:635.926

MUHAMMAD JAVED ${ }^{2}$

AAMIR IQBAL ${ }^{1}$

MIAN NAZIR SHAH ${ }^{2}$

SAMIULLAH KHAN ${ }^{2}$

ABDUR RAHMAN SIAL ${ }^{1}$

KARKACH PETER ${ }^{3}$

MASHKIN YURIY ${ }^{3}$

NATALIIA VOVKOTRUB ${ }^{3}$

ISMAIL BAYRAM ${ }^{1}$

${ }^{1}$ Afyon Kocatepe University, Afyonkarahisar, Turkey

${ }^{2}$ University of Agriculture, Peshawar, Pakistan

${ }^{3}$ Bila Tserkva National Agrarian University Ukraine

\title{
EFFECT OF AQUEOUS EXTRACT PLANT MIXTURE ON LIPID PROFILE AND HEPATOTOXICITY OF BROILER CHICKS
}

A research study was conducted to find the effect aqueous extract mixture of Zingiberofficinale, Carumcapticum, Withania somnifera, Trigonella foenum graecum, Silybummarianum, Allium sativum and Berberis lyceum on the growth performance of internal organs, lipid profile and hepatotoxicity of broiler chicks. A total of 240 day old chicks were purchased and were reared for 35 days in summer month. The birds were raised on conventional deep litter system, in open shed and all the pens/cages were placed in the same shed to ensure the same environment for all of the groups. Each pen was provided with a feeder and drinker. This aqueous extract mixture of plant was then mixed in drinking water of chicks at the rate of @ 0.0,5.0, 10.0 and $15.0 \mathrm{ml} / \mathrm{L}$ for group A, B, C and D, respectively while group A served as a control. Feed and water were provided on calculated basis. Total numbers of chicks were divided into four groups (A, B, C and D) each having 60 chicks. Each group was further subdivided into three groups (replicates) each having 20 chicks. The data were recorded to explore the effect of infusion based plant mixture on the lipid profile and hepatotoxicity. AST and ALP had significantly $(\mathrm{P}<0.05)$ decreasing trend in groups $\mathrm{B}, \mathrm{C} \& \mathrm{D}$. ALT was significantly $(\mathrm{P}<0.05)$ lower in Group B. Group D had significantly $(\mathrm{P}<0.05)$ lower cholesterol, Triglyceride and LDL and higher HDL values. Serum protein were significantly $(\mathrm{P}<0.05)$ higher in group A. Group B @ $5.0 \mathrm{ml} / \mathrm{L}$ of Aqueous Extract water to improve liver function. Lipid profile could be well controlled, while using plant mixture extract @ $15.0 \mathrm{ml} / \mathrm{L}$ of water. Therefore the use of these medicinal plants is of great concern especially for broiler hepatic-toxicity and lipid profile.

Keywords: Broilers, lipid profile, hepatotoxicity, higher density lipoprotein.

\section{doi: 10.33245/2310-9289-2019-150-2-131-136}

Formulation of the problem. Feed has a pivotal role for net return from the poultry Industry, because $80 \%$ of the total input cost is spent on feed purchase. With the passage of time, meat requirement has increased. For health maintenance, nutrition in terms of macro and micro-nutrients play a major role in livestock production. In Pakistan the available animal protein is insufficient for human utilization because of too much high price of meat which is out of public approach and hence, it affects the health and fitness of the population (Farooq et al., 2001). To ensure more net return and to minimize high expenditure on feed are the main challenges, for which many research plans have been practiced such as introducing feed supplements and feed additives. Pakistan is an agriculture country and livestock is the most important sector of our country. It contributed to agriculture sector about $55.9 \%$ while it contributed $11.8 \%$ to the national GDP (Pervez et al. 2005). In the past the major growth promoters were antibiotics. The provision of quality of protein by the poultry in the form of meat and egg has diverted the attention of nutritionists to emphasize on the quality of balanced ration of poultry feed. Feed additives, including antibiotics play a key role in the proper utilization of feed ingredients with the objective to improve their feed efficiency. As a result negative effects have been experienced in the accumulation of residues and development of resistance of microorganisms against antibiotics therefore; the prevention of harmful diseases is a great challenge for the scientists in the present scenario. Present research is looking for natural alternative to antibiotics because of their residue and subsequent resistance to bacteria (Lee 2004).

\footnotetext{
${ }^{\odot}$ Muhammad Javed, Aamir Iqbal, Mian Nazir Shah, Samiullah Khan, Abdur Rahman Sial, Karkach Peter, Mashkin Yuriy, Nataliia Vovkotrub, Ismail Bayram, 2019.
} 
At present the scientists are working to improve feed efficiency and growth rate of livestock using useful herbs. To cope with the shortage of animal protein availability, it is necessary to enhance the growth of small livestock with minimum cost. Livestock plays a vital role in developed countries in terms of food, financial and social aspect (Abu-Dieyeh and Abu-Darwish 2008). There is little published data concerning with using Zingiber officinale, Carum capticum, withania somnifera, Trigonella Foenum Graecum, Silybum marianum, Allium sativum and Berberis lycium, as a natural feed additive in poultry nutrition. These plants have been reported for various functions like antibacterial, antiseptic, anti-inflammatory, antiparasitic and immunological properties. Therefore the use of these medicinal plants is of great concern especially for broiler hepatic-toxicity and lipid profile. The objective of this project was to evaluate the effect of medicinal plants on lipid profile and hepatic-toxicity of broiler chicks by using them in drinking water. In order to explore the effects of Zingiber officinale, Carum capticum, withania somnifera, Zingiberofficinale, Carumcapticum, Withania somnifera, Trigonella foenum graecum, Silybummarianum, Allium sativum and Berberis lyceum, the powder of all these was used in drinking water to see the effect on Lipid Profile and Hepatotoxicity.

Material and methods of research. The current study was performed at Department of Poultry Science, University of Agriculture, and Peshawar Pakistan after the approval of the Local Ethics Committee under approval No: Agri-781 on 25-08-2018.

The experiment was conducted in completely randomized design (CRD). A total of 240 zero day old commercial broiler chicks were purchased from the local market and were divided into four groups A, B, C and D. Each group was further divided into three replicates having 20 chicks/replicate. The birds were raised on conventional deep litter system, in open shed and all the pens / cages were placed in the same shed to ensure the same environment for all of the groups. Each pen was provided with a feeder and drinker. The experiment lasted for 35 days.

Application of plant mixture to drinking water. Experimental plants (Zingiber officinale, Carum capticum, Withania somnifera, Trigonella foenum graecum, Silybum marianum, Allium sativum and Berberis lycium) were purchased from local market. The plant parts (fruit, leaves, and root) were cut into small pieces, and then were dried and grinded into powder form. Five gm from each of plants powder was mixed in one liter of water. This aqueous extract mixture of plant was then mixed in drinking water of chicks at the rate of @ 0.0,5.0,10.0 and $15.0 \mathrm{ml} / \mathrm{L}$ for group A, B, C and D, respectively.

The data was statistically analyzed with the standard procedures of analysis of variance (ANOVA), using Completely Randomized Design. Means were compared for significance of differences by least significance differences (LSD) as suggested by (Calinski, Steel, and Torrie 1981). The statistical package (Singer 1998) was used to perform the above analysis on computer.

Main results of the study. Data on Intestine weight, Abdominal Fat weight, Gizzard weight, Heart weight, Liver weight is presented in Table-1 and data about the Liver Enzymes AST, ALT, ALP is in Table-2 while of , Serum protein, HDL,LDL, Cholesterol, Triglyceride is mentioned in Table-3. Average intestine weights for the four experimental groups are given in table 1 . The mean intestine weight was $80.16,87.16,88.00$ and $82.00 \mathrm{~g}$ for groups $\mathrm{A}, \mathrm{B}, \mathrm{C}$ and D respectively and that of vaccinated and non-vaccinated was 86.75 and $81.91 \mathrm{~g}$ respectively. Average fat weights for the four experimental groups are given in table 1.

Table $1-$ Mean \pm SE of different parameters in response of aqueous extract of different plants

\begin{tabular}{|c|c|c|c|c|c|}
\hline \multicolumn{5}{|c|}{ Groups } & \multirow[b]{2}{*}{$p$} \\
\hline & A & B & $\mathrm{C}$ & $\mathrm{D}$ & \\
\hline Parameters & $0 \mathrm{ml}$ & $5 \mathrm{ml}$ & $10 \mathrm{ml}$ & $15 \mathrm{ml}$ & \\
\hline Intestine $(\mathrm{g})$ & $80.16 \pm 0.125$ & $87.16 \pm 0.541$ & $88.00 \pm 0.124$ & $82.00 \pm 0.321$ & 0.547 \\
\hline Abdominal Fat (g) & $17.48 \pm 0.142$ & $14.76 \pm 0.621$ & $13.28 \pm 0.214$ & $15.05 \pm 0.214$ & 0.092 \\
\hline Gizzard (g) & $19.33 \pm 0.147$ & $20.60 \pm 0.214$ & $22.66 \pm 0.321$ & $21.83 \pm 0.174$ & 0.745 \\
\hline Heart (g) & $8.00 \pm 1.024$ & $8.30 \pm 0.124$ & $8.58 \pm 0.142$ & $8.46 \pm 0.321$ & 0.614 \\
\hline Liver (g) & $29.00 \pm 0.514$ & $32.33 \pm 0.124$ & $35.00 \pm 0.521$ & $31.66 \pm 0.124$ & 0.874 \\
\hline
\end{tabular}

The mean abdominal fat weight was $17.48,14.76,13.28$ and $15.05 \mathrm{~g}$ for groups A, B, C and D respectively and that of vaccinated and non-vaccinated was 15.20 and $15.09 \mathrm{~g}$ respectively. Average Gizzard weight per chick at the end of experiment are 19.33, 20.60, 22.66 and 21.83g respectively for groups A, B, C and D. Gizzard weight of subgroups of vaccinated and non-vaccinated was 20.96 and 
$21.25 \mathrm{~g}$ respectively (Table 1$)$. The gizzard weight data showed non-significant $(\mathrm{P}>0.05)$ difference among the treatments, vaccinated chicks, non-vaccinated chicks and within groups Statistics showed that gizzard weight was numerically higher in group $\mathrm{C}$ as compared to other groups. Mean heart weight per chick at the end of experiment was $8.00,8.30,8.58$ and $8.46 \mathrm{~g}$ for groups $\mathrm{A}, \mathrm{B}, \mathrm{C}$ and $\mathrm{D}$, respectively. Heart weight of subgroups of vaccinated and non-vaccinated was 8.25 and $8.44 \mathrm{~g}$ respectively (Table 1$)$. The heart weight data showed non-significant $(\mathrm{P}>0.05)$ difference among the treatments, vaccinated and non vaccinated groups.

Statistics revealed that group $\mathrm{C}$ had numerically higher heart weight than others. Average liver weight for the four experimental groups A, B, C and D, were 29.00, 32.33, 35.00 and $31.66 \mathrm{~g}$ respectively (Table 1), while in the subgroups of vaccinated and non-vaccinated liver weight was 33.41 and $30.58 \mathrm{~g}$ respectively. The liver weight data when subjected to analysis of variance showed non-significant $(\mathrm{P}>0.05)$ difference among the groups, vaccinated and non-vaccinated chicks. However the liver weight was found numerically higher in group $\mathrm{C}$ as compared to other groups. Average serum AST (aspartate aminotransferase) value per chick at the end of experiment was 71.5, $46.33,47.16$ and 53.33 for group A, B, C and D respectively, (Table 2). Average values of vaccinated and non-vaccinated groups were 63.50 and 45.66 respectively.

Table 2 - Mean \pm SE of different parameters in response of aqueous extract of different plants

\begin{tabular}{|l|c|c|c|c|}
\hline \multicolumn{3}{|c|}{ Groups } & C & D \\
\hline Parameters & A & B & $10 \mathrm{ml}$ & $15 \mathrm{ml}$ \\
\hline AST & $0 \mathrm{ml}$ & $5 \mathrm{ml}$ & $47.16 \pm 0.051^{\mathrm{b}}$ & $53.33 \pm 0.013^{\mathrm{b}}$ \\
\hline ALT & $71.5 \pm 0.012^{\mathrm{a}}$ & $46.33 \pm 0.014^{\mathrm{b}}$ & $54.16 \pm 0.081^{\mathrm{bc}}$ & $64.83 \pm 0.023^{\mathrm{bc}}$ \\
\hline ALP & $74.5 \pm 0.017^{\mathrm{a}}$ & $50.33 \pm 0.084^{\mathrm{c}}$ & $143.50 \pm 0.051$ & $153.00 \pm 0.041$ \\
\hline Serum protein & $217.83 \pm 0.034^{\mathrm{a}}$ & $141.33 \pm 0.041$ & $5.18 \pm 0.061^{\mathrm{b}}$ & $6.44 \pm 0.051^{\mathrm{a}}$ \\
\hline
\end{tabular}

The AST data was subjected to analysis of variance revealed significant $(\mathrm{P}<0.05)$ difference among the groups and between the vaccinated and non-vaccinated subgroups. Similarly significant $(\mathrm{P}<0.05)$ difference was found among the group interaction. AST was significantly $(\mathrm{P}<0.05)$ reduced in group $\mathrm{B}$ as compared to group A. No significant $(\mathrm{P}>0.05)$ difference was recorded in groups $\mathrm{C}$ and $\mathrm{D}$. Average serum ALP (alkaline phosphatase) value per chick at the end of experiment was 217.83, 141.33, 143.50 and 153.00 for group A, B, C and D respectively (Table 2). Average values of vaccinated and non-vaccinated groups were 170.08 and 157.75 , respectively. The ALP data was subjected to analysis of variance revealed significant $(\mathrm{P}<0.05)$ difference among the groups and non-significant difference $(\mathrm{P}>0.05)$ between the vaccinated and non-vaccinated subgroups and the group interaction. Numerically reduced ALP was observed in group B as compared groups C and D. Average ALT value per chick at the end of experiment was $74.50,50.33,54.16$ and 64.83 for group A, B, C and D, respectively (Table 2). Average values of vaccinated and non-vaccinated groups were 67.66 and 54.25, respectively. Significant $(\mathrm{P}<0.05)$ difference was observed on the mean ALT levels among the treatments and between the vaccinated and nonvaccinated groups and also among the group interaction. However, group B was observed with lowest significant $(\mathrm{P}<0.05)$ calculate ie. $50.33 \mathrm{iu} / \mathrm{ml}$.

Average serum protein value per chick at the end of experiment was 6.95, 4.81, 5.18 and 6.44 for group A, B, C and D respectively, (Table 2). Average values of vaccinated and non-vaccinated groups were 6.40 and 5.29 respectively. Significant $(\mathrm{P}<0.05)$ difference was observed on the mean serum protein levels among the treated and between the vaccinated and non-vaccinated and also among the group interaction. The result of the present study showed that group A was found with significantly $(\mathrm{P}<0.05)$ higher serum protein as compared to the others groups.

Average Cholesterol value per chick at the end of experiment was 138.00, 106.83, 99.46 and 49.33. For group $\mathrm{A}, \mathrm{B}, \mathrm{C}$ and $\mathrm{D}$, respectively while vaccinated and non-vaccinated groups were 100.66 and 96.25 respectively (Table 3). Average triglyceride values were 103.00, 91.33, 73.83 and 40.83 for group A, B, C and D, respectively while vaccinated and non-vaccinated groups were77.83 and 76.66 respectively (Table 3$)$. Significant $(\mathrm{P}<0.05)$ differences in the mean serum total cholesterol and triglyceride values were recorded among the treatments and non-significant $(\mathrm{P}>0.05)$ in vaccinated and non-vaccinated groups. No significant $(P>0.05)$ difference was recorded among the group interaction. Total serum cholesterol and triglyceride values were found significantly $(\mathrm{P}<0.05)$ 
lowered in group D as compared to control group. Average HDL value per chick at the end of experiment was $32.16,37.66,41.50$ and $75.66 \mathrm{mg} \%$ for group A, B, C and D, respectively (Table 3). Average values of vaccinated and non-vaccinated groups were 48.25 and $45.25 \mathrm{mg} \%$ respectively significantly high $(\mathrm{P}<0.05)$ HDL values were observed in group $\mathrm{D}$ than control group and nonsignificant difference $(P>0.05)$ between the vaccinated and non-vaccinated. Similarly no significant $(\mathrm{P}>0.05)$ difference was found among the group interaction. Average LDL value per chick at the end of experiment was $63.16,47.83,32.50$ and $15.16 \mathrm{mg} \%$ for group A, B, C and D, respectively (Table $3)$. Average values of vaccinated and non-vaccinated groups were 41.25 and $38.08 \mathrm{mg} \%$ respectively Mean serum low-density lipoprotein values were found significant $(\mathrm{P}<0.05)$ among the treatments and non-significant $(\mathrm{P}>0.05)$ between the vaccinated and non-vaccinated.

Table 3 - Mean $\pm \mathbf{S E}$ of different parameters in response of aqueous extract of different plants

\begin{tabular}{|l|c|c|c|c|}
\hline \multicolumn{5}{|c|}{ Groups } \\
\hline \multirow{3}{*}{ Parameters } & A & B & C & D \\
\cline { 2 - 5 } & $0 \mathrm{ml}$ & $5 \mathrm{ml}$ & $10 \mathrm{ml}$ & $15 \mathrm{ml}$ \\
\hline HDL & $32.16 \pm 0.012^{\mathrm{c}}$ & $37.66 \pm 0.142^{\mathrm{bc}}$ & $41.50 \pm 0.412^{\mathrm{b}}$ & $75.66 \pm 0.174^{\mathrm{a}}$ \\
\hline LDL & $63.16 \pm 0.124^{\mathrm{a}}$ & $47.83 \pm 0.014^{\mathrm{b}}$ & $32.50 \pm 0.132^{\mathrm{c}}$ & $15.16 \pm 0.054^{\mathrm{d}}$ \\
\hline Cholesterol & $138.00 \pm 0.541^{\mathrm{a}}$ & $106.83 \pm 0.014^{\mathrm{b}}$ & $99.46 \pm 0.174^{\mathrm{b}}$ & $49.33 \pm 0.251^{\mathrm{c}}$ \\
\hline Triglyceride & $103.00 \pm 0.124^{\mathrm{a}}$ & $91.33 \pm 0.147^{\mathrm{b}}$ & $73.83 \pm 0.0621^{\mathrm{c}}$ & $40.83 \pm 0.412^{\mathrm{d}}$ \\
\hline
\end{tabular}

Group Similarly significant $(\mathrm{P}<0.05)$ difference was found among the group interaction. However, significantly $(\mathrm{P}<0.05)$ lower serum low-density lipoprotein value was recorded in treatment $\mathrm{D}(15.16$ $\mathrm{mg} \%$ ) than control.

Discussion. Average intestine weights for the four experimental groups are given in table 1 . The mean intestine weight was $80.16,87.16,88.00$ and $82.00 \mathrm{~g}$ for groups $\mathrm{A}, \mathrm{B}, \mathrm{C}$ and D respectively. And that of vaccinated and non-vaccinated was 86.75 and $81.91 \mathrm{~g}$ respectively. The results are in agreement with average fat weights for the four experimental groups are given in table 1 . The mean abdominal fat weight was $17.48,14.76,13.28$ and $15.05 \mathrm{~g}$ for groups $\mathrm{A}, \mathrm{B}, \mathrm{C}$ and D respectively and that of vaccinated and nonvaccinated was 15.20 and $15.09 \mathrm{~g}$ respectively. The results of present study are aligned with (Santoso, Setianto, and Suteky 2005). The gizzard weight data showed non-significant $(\mathrm{P}>0.05)$ difference among the treatments, vaccinated chicks, non-vaccinated chicks and groups interaction. Statistics showed that gizzard weight was numerically higher in group $\mathrm{C}$ as compare to other groups. Similar findings were found in the study conducted by (Santoso, Kususiyah, and Fenita 2010). Mean heart weight per chick at the end of experiment was $8.00,8.30,8.58$ and $8.46 \mathrm{~g}$ for groups A, B, C and D, respectively. Heart weight of subgroups of vaccinated and non-vaccinated was 8.25 and $8.44 \mathrm{~g}$ respectively (Table 1). The heart weight data showed non-significant $(\mathrm{P}>0.05)$ difference among the treatments, vaccinated and non-vaccinated groups. Statistics revealed that group $\mathrm{C}$ had numerically higher heart weight than others. The liver weight data when subjected to analysis of variance showed non-significant $(\mathrm{P}>0.05)$ difference among the groups, vaccinated and non-vaccinated chicks. However the liver weight was found numerically higher in group C as compared to other groups. Similar results were obtained in the study conducted by (Santoso and Sartini 2001)(Santoso, Kususiyah, and Fenita 2010). This non-significant result might relate to the same active compounds concentration in each extract. The main active compound affected fat accumulation might be methyl-pyro-glutamate which is converted to glutamate. The stimulation of protein synthesis by glutamate may not reduce substrate supply for fatty acid synthesis. Furthermore, glutamate could further be converted to L-arginine and then to nitric oxide. Nitric oxide could not block LDL oxidation and did not reduce atherosclerosis (Cooke, 1998; Drexler, 1999; Napoli and Ignarro, 2001). The non-reduction of fat deposition might partly be caused by methyl-pyro-glutamate. Methylpyroglutamate might not convert to glutamic acid in the gut.

The table 2 is about values of different enzymes, here in this study trial the AST data was subjected to analysis of variance revealed significant $(\mathrm{P}<0.05)$ difference among the groups and between the vaccinated and non-vaccinated subgroups. AST was significantly $(\mathrm{P}<0.05)$ reduced in group $\mathrm{B}$ as compared to group A. No significant $(\mathrm{P}>0.05)$ difference was recorded in groups $\mathrm{C}$ and D. Similar results were found in the study of (Emadi and Kermanshahi 2007); (Prakash et al. 2010) and (Sapkota et al. 2017) where there was significant difference in liver enzymes. The ALP data was subjected to analysis of variance revealed significant $(\mathrm{P}<0.05)$ difference among the groups and non-significant 
difference $(\mathrm{P}>0.05)$ between the vaccinated and non-vaccinated subgroups and the group interaction. Numerically reduced ALP was observed in group B as compared groups C and D. the results were aligned with the findings of (Manan et al. 2012). Significant $(P<0.05)$ difference was observed on the mean ALT levels among the treatments and between the vaccinated and non-vaccinated groups and also among the group interaction. However, group B was observed with lowest significant $(\mathrm{P}<0.05)$ calculate ie. $50.33 \mathrm{iu} / \mathrm{ml}$. similar findings were observed in (Manan et al. 2012) where Significant $(P<0.05)$ difference was observed on the mean ALT levels among the different groups. The significant decrease in ALT was also reported by (Researchers, Club, and Branch 2016). Significant $(\mathrm{P}<0.05)$ difference was observed on the mean serum protein levels among the treated and between the vaccinated and nonvaccinated and also among the group interaction. The result of the present study showed that group A was found with significantly $(\mathrm{P}<0.05)$ higher serum protein as compared to the others groups. Similar findings were observed in the study conducted by (Chen et al. 2003).

This present findings suggest that the mixture of plant extract mixture supplementation in feed is effective in regulation of lipid metabolism in broilers. Similarly, it shows effective results in lowering the total cholesterol via its effect on the plasma concentration of LDL cholesterol.

In table 3 total serum cholesterol and triglyceride values were found significantly $(\mathrm{P}<0.05)$ lowered in group D as compared to control group. Average HDL value per chick at the end of experiment was 32.16, 37.66, 41.50 and $75.66 \mathrm{mg} \%$ for group A, B, C and D, respectively (Table 3). Similar results were observed in the study conducted by (Shim et al. 2004). Average values of vaccinated and non-vaccinated groups were 48.25 and $45.25 \mathrm{mg} \%$ respectively significantly high $(\mathrm{P}<0.05) \mathrm{HDL}$ values were observed in group $\mathrm{D}$ than control group and non-significant difference $(\mathrm{P}>0.05)$ between the vaccinated and non-vaccinated. Similarly no significant $(\mathrm{P}>0.05)$ difference was found among the group interaction. The results were in agreement with (Santoso, Setianto, and Suteky 2005). Mean serum low-density lipoprotein values were found significant $(\mathrm{P}<0.05)$ among the treatments and non-significant $(\mathrm{P}>0.05)$ between the vaccinated and non-vaccinated. Group Similarly significant $(\mathrm{P}<0.05)$ difference was found among the group interaction. However, significantly $(\mathrm{P}<0.05)$ lower serum low-density lipoprotein value was recorded in treatment D $(15.16 \mathrm{mg} \%)$ than control. Similar findings were obtained in the study conducted by (Santoso, Setianto, and Suteky 2005). This difference might relate to the different active compounds concentration in each extract. The main active compound affected fat accumulation might be methyl-pyro-glutamate which is converted to glutamate. The stimulation of protein synthesis by glutamate may reduce substrate supply for fatty acid synthesis. Furthermore, glutamate could further be converted to L-arginine and then to nitric oxide. Nitric oxide could block LDL oxidation and reduced atherosclerosis.

Conclusion. Present study was used to explore the effects of Zingiber officinale, Carum capticum, Withania somnifera, Trigonella foenum graecum, Silybum marianum, Allium sativum and Berberis lyceum on the growth and performance of broiler chicks. Such plants have been reported for various functions like antibacterial, antiseptic, anti-inflammatory, anti-parasitic and immunological properties. Therefore the use of these medicinal plants is of great concern especially for broiler hepatic-toxicity and lipid profile. This difference and effect might be related to the different active compounds concentration in each extract. The main active compound affected different body function. Hence, active compounds could have anti-inflammatory as well as antioxidant effects through COX-2 inhibition pathway like non-steroidal anti-inflammatory drugs. It is recommended to conduct more research during prolonged storage at higher temperatures to explore more effects on different parameters.

\section{REFERENCES}

1. Farooq, M., Mian M. A., Asghar, A. (2001). Factors affecting cost of production and net profit per broiler in the subtropics. Livestock Research for Rural Development. Vol. 13, Article no. 4, Retrieved October 21, 2019. URL: http://www.lrrd.org/lrrd13/1/faro131.htm

2. Abu-Dieyeh, Ziad H.M., Mohammad, S. Abu-Darwish. (2008). "Effect of Feeding Powdered Black Cumin Seeds (Nigella Sativa L.) on Growth Performance of 4-8 Week-Old Broilers." Journal of Animal and Veterinary Advances.

3. Calinski, T., Steel, R. G. D., Torrie, J. H. (1981). "Principles and Procedures of Statistics: A Biometrical Approach." Biometrics.

4. Chen, Yuwei., Boqiang, Qin., Katrin, Teubner., Martin, T. Dokulil. (2003). "Long-Term Dynamics of Phytoplankton Assemblages: Microcystis-Domination in Lake Taihu, a Large Shallow Lake in China." Journal of Plankton Research.

5. Emadi, M., Kermanshahi, H. (2007). "Effect of Turmeric Rhizome Powder on the Activity of Some Blood Enzymes in Broiler Chickens.” International Journal of Poultry Science. 6(1), pp. 48-51.

6. Lee, Hau L. (2004). “The Triple-A Supply Chain.” Harvard Business Review. 
7. Manan, Abdul et al. (2012). "Effect of Periodic Supplementation of Herbal Infusion on the Liver Function and Lipid Profile of Broiler Chickens.” 28(1).

8. Pervez, Amjad., Syed, Muzaffar Ahmed., Abdul, Aziz Khan., Shaher, Bano Lathiya. (2005). "Comparative Field Efficacy of Some Additive Formulated Baits against Rodent Pests of Wheat Crop in Sindh, Pakistan.” Pakistan Journal of Zoology.

9. Prakash, A. et al. (2010). "Protective Effect of Ocimum Sanctum on Disposition Kinetics of Sulphadimidine in LeadTreated Cockerel.” Iranian Journal of Pharmacology and Therapeutics.

10. Researchers, Young., Elite, Club., Shahrekord, Branch. (2016). "On the Pathological and Biomedical Indexes ".

11. Santoso, U., Kususiyah, K., Fenita, Y. (2010). "The Effect Of Sauropus Androgynus Extract And Lemuru Oil On Fat Deposition And Fatty Acid Composition Of Meat In Broiler Chickens.” Journal Of The Indonesian Tropical Animal Agriculture. 35(1), pp. 48-54.

12. Santoso, U., and Sartini. (2001). "Reduction of Fat Accumulation in Broiler Chickens by Sauropus Androgynus (Katuk) Leaf Meal Supplementation.” Asian-Australasian Journal of Animal Sciences. 14(3), pp. 346-350.

13. Santoso, U., Setianto, J., Suteky, T. (2005). "Effect of Sauropus Androgynus (Katuk) Extract on Egg Production and Lipid Metabolism in Layers." Asian-Australasian Journal of Animal Sciences. 18(3), pp. 364-369.

14. Sapkota, Yadav. (2017). "Meta-Analysis Identifies Five Novel Loci Associated with Endometriosis Highlighting Key Genes Involved in Hormone Metabolism." Nature Communications.

15. Shim, K. S., Park, G. H., Choi, C. J., Na, C.S. (2004). "Decreased Triglyceride and Cholesterol Levels in Serum, Liver and Breast Muscle in Broiler by the Supplementation of Dietary Codonopsis Lanceolata Root." Asian-Australasian Journal of Animal Sciences. 17(4), pp. 511-513.

16. Singer, Judith D. (1998). "Using SAS PROC MIXED to Fit Multilevel Models, Hierarchical Models, and Individual Growth Models." Journal of Educational and Behavioral Statistics.

Влив суміші водного екстракту рослин на ліпідний профіль та гепатотоксичність курчат-бройлерів Мухамед Джаве, Амір Ікбал, Міан Назір Шах, Саміулах Хан, Абдур Рахман Сіал, Петро Каркач, Юрій Машкін, Наталія Вовкотруб, Ісмаіл Байрам

3'ясовано вплив водної екстракційної суміші Zingiberofficinale, Carumcapticum, Withania somnifera, Trigonella foenum graecum, Silybummarianum, Allium sativum i Berberis lyceum на показники росту внутрішніх органів, ліпідного профілю і гепатотоксичності курчат-бройлерів. Усього було придбано 240 добових курчат, яких вирощували протягом 35 діб у літні місяці. Корм і воду було надано на розрахунковій основі. Курчат було розділено на чотири групи (А, В, С і D), по 60 голів у кожній. Кожна група була додатково розділена на три групи (повтори) по 20 курчат. Птицю вирощували за звичайною системою глибокої підстилки, у відкритому шеді, і всі загони / клітки були розміщені в одному шеді, щоб забезпечити однакові умови для птиці всіх груп. Птицю було забезпечено фронтом годівлі та напування. Водну екстракційну суміш рослин змішували у питній воді для курчат у кількості 5,0; 10,0 та 15,0 мл/л для груп В, С і D відповідно, тимчасом група А служила контролем. Збір даних було проведено для вивчення впливу водного екстракту рослинної суміші на ліпідний профіль і гепатотоксичність. АСТ і АЛТ значно знижувалися $(\mathrm{P}<0,05)$ в групах $\mathrm{B}, \mathrm{C}$ i D. АЛТ була значно $(\mathrm{P}<0,05)$ нижчою в групі В. Група D мала значно $(\mathrm{P}<0,05)$ нижчий рівень холестерину, тригліцеридів i LDL, i вищі значення HDL. Cироватковий білок був значно $(\mathrm{P}<0,05)$ вищим у групі А. У групі $\mathrm{B}$, яка отримувала 5 мл/л водного екстракту з водою, поліпшувалася функція печінки. Ліпідний профіль можна ефективно контролювати, використовуючи екстракт рослинної суміші в кількості 15 мл/л води. 3 огляду на це, використання цих лікарських рослин має велике значення, особливо для гепатотоксичності бройлерів і ліпідного профілю.

Ключові слова: бройлери, ліпідний профіль, гепатотоксичність, ліпопротеїни високої щільності.

Влияние смеси водного экстракта растений на липидный профиль и гепатотоксичность цыплятбройлеров

Мухамед Джаве, Амир Икбал, Миан Назир Шах, Самиулах Хан, Абдур Рахман Сиал, Петро Каркач, Юрий Машкин, Наталия Вовкотруб, Исмаил Байрам

Изучено влияние водной экстракционной смеси Zingiberofficinale, Carumcapticum, Withania somnifera, Trigonella foenum graecum, Silybummarianum, Allium sativum и Berberis lyceum на показатели роста внутренних органов, липидного профиля и гепатотоксичности цыплят-бройлеров. Всего было приобретено 240 суточных цыплят, которые выращивались в течение 35 суток в летние месяцы. Корм и вода были предоставлены на расчетной основе. Цыплята были разделены на четыре группы (A, B, C и D), по 60 голов в каждой. Каждая группа была дополнительно разделена на три группы (повторы) по 20 цыплят. Птицу выращивали по обычной системе глубокой подстилки, в открытом шэде, и все изгороди / клетки были размещены в одном шэде, чтобы обеспечить одинаковые условия для птицы всех групп. Вся птица была обеспечена фронтом кормления и выпаивания. Водную экстракционную смесь растений смешивали в воде для цыплят в количестве 5,$0 ; 10,0$ и 15,0 мл/л для групп В, С и D соответственно, тогда как группа А служила контролем. Сбор данных провели для изучения влияния водного экстракта растительной смеси на липидный профиль и гепатотоксичность. АСТ и АЛТ значительно снижались $(\mathrm{P}<0,05)$ в группах В, C и D. АЛТ была значительно $(\mathrm{P}<0,05)$ ниже в группе В. Группа D имела значительно (P <0,05) ниже уровень холестерина, триглицеридов и LDL, и более высокие значения HDL. Сывороточный белок был значительно (P <0,05) выше в группе А, В группе В, которая получала 5 мл/л водного экстракта с водой, улучшалась функция печени. Липидный профиль можно еффективно контролировать, используя экстракт растительной смеси в количестве 15 мл/л воды. Поэтому использование этих лекарственных растений имеет большое значение, особенно для гепатотоксичности бройлеров и липидного профиля.

Ключевые слова: бройлеры, липидный профиль, гепатотоксичность, липопротеины высокой плотности.

Надійшла 25.09.2019 p.

NATALIIA VOVKOTRUB, https://orcid.org/0000-0003-3297-454X 